\title{
The Challenges and Prospects of Science Education Development in Africa
}

\author{
Margaret Foluso Ayeni \\ Department of Science Education, Faculty of Education, \\ Ekiti State University, Ekiti, Nigeria
}

DOI: https://doi.org/10.36941/mjss-2021-0033

\begin{abstract}
In spite of the numerous groundbreaking innovations and inventions that science education can achieve in Africa, its growth in the continent is stunted. This retardation in development is as a result of fundamental problems which are discussed in the paper under the following headings: Insecurity, corruption, Unavailability of Laboratory Equipment and Instructional materials, Inadequate Funds, Inadequate Teacher Quality and Teaching Method, Difficult concepts in science. The paper highlights the challenges crippling the development of science education and the prospects its growth will have in the growth of Africa as a continent. Also, this paper focuses on the challenges plaguing science education in African Countries. It intends to reveal how science education is being prevented from becoming prominent in the national and sustainable development of African countries. It also discusses the prospects science education will have in the development of the continent if it was not plagued with difficulties. Some recommendations were made on the steps to take to improve the development of science education in Africa.
\end{abstract}

Keywords: challenges, prospect, science education and development

\section{Introduction}

A nation's development is not measured through the number of buildings it has, the roads laid down, or bridges constructed but by the human resources developed by the nation through a well-defined system of education (Bhoje, 2014). Education has been defined and conceptualised by different educationists, philosophers and authors. As summarized by Nnaboua and Asodike (2014), Education is a process of acquiring knowledge and ideas that shape and condition man's attitude, actions and achievements; it is the art of the utilization of knowledge for complete living; it is a process of developing the child's moral, physical, emotional and intellectual power for his contribution in social reform; it is the process of mastering the laws of nature, utilizing them effectively for the welfare of the individual and for social reconstruction; it is power. Nelson Mandela rightly quoted "Education is the most powerful weapon which you can use to change the world" (Duncan, 2013). Therefore, for national development and particularly, sustainable development of every nation, a sound educational system is critical (Sani \& Ikpe, 2019).

Aina (2012) defined science as a body of knowledge characterized by unbiased observation and systematic experimentation. It is the bedrock upon which any nation can be built; this insinuates that scientific advancement is germane for any nation that wants to be globally recognized (Onah, 2003). The word Science is derived from the Latin word "Scientia" which means what is to be known, truth, certain or what is a fact (Onyeukwu \& Enyaosah, 2016). It could be viewed as an act of doing and is more involved with various investigative activities and processes regarding developing, controlling 
and acquiring skills, knowledge, attitude and capacity about the natural factors of the environment. This suggests that science is a way of knowing, theories, facts among others (Okoli et al., 2013). In Africa, as most continents, science is viewed as a key element of schooling, and higher education in science subjects is usually regarded as major importance for meeting societal needs such as guaranteeing the availability of scientists, engineers and other professionals working in scientific fields and for ensuring sustainable economic development (Taber, 2017).

Science education is the application of educational (learning) theories especially those based on the philosophical, sociological and psychological perspectives in the endless search for knowledge, which results in the development of the intellectual, psychomotor domains through some systematic processes involving careful observation, deduction and testing by empirical means (Igbaji et al., 2017). It is a fusion between the elements of science and education, to produce a simplified and comprehensible concept of science that can be understood by individuals not traditionally part of the scientific community. It should be able to transform the typical teacher-centered classroom lecture into a discovery and problem-solving arena. This stimulates creativity and originality; and to achieve this, the students have to be actively engaged in identifying problems and search for the solutions. (Ohunene \& Ebele, 2014).

According to Pember and Humbe (2009), Science Education is the process of teaching or training particularly, in school to improve one's knowledge about the environment, develop one's skill of systematic inquiry and also natural attitudinal characteristics. It is geared towards acquiring critical thinking and exploration, which leads to sustainable development (Sani \& Ikpe, 2019). This is in line with Okafor, (2004) who states that the main of purpose of science education is to promote scientific and technological literacy which helps individuals develop the ability to apply scientific knowledge creatively in everyday life; makes them familiar with some processes of science that are helpful in decision making and problem making; help them understand scientific issues involved in handling household technological devices; help develop empathy, understand scientific issues involved in handling household technological device and make appropriate decisions that are related to health, nutrition, environment, education and lifestyles among others.

Science education is very important to the development of any nation in many areas especially scientific and technological advancement (Sani \& Ikpe, 2019). It comprises of three subjects namely biology, chemistry and physics; and if well-developed will represent a catalytic process for educational training, public awareness, values, behaviour and lifestyles required for a sustainable human and capital development (Badmus \& Omosewo, 2018).

The benefits of science education in Africa cannot be overemphasized and one major effect is in the area Information and communication Technology (ICT). Science helps humans gain increased understanding of how the world works, while technology helps scientists make these discoveries (Yoldere \& Adamu, 2014). Despite all the benefits derived from science education, its development seems to be drowning due to several challenges in Africa.

\section{Challenges Facing the Development of Science Education in Nigeria}

There are several problems in the Education system of African Countries. Since no nation can advance without prioritizing the development of Science Education, it is necessary to analyze some of the challenges facing science education in African countries and suggest ways these challenges might be addressed (Yoldere \& Adamu, 2014). These problems are discussed under the following headings:

\section{Insecurity}

The issue of security in Africa has been disastrous, causing a lot of fear and chaos for the past decade. Insecure school environment can trigger traumatic disorder and toxic stress that affect learning negatively (Akintunde \& Selzing-Musa, 2016). Insecurity in Academic Environment seems to be on the rise with the tragic occurrences happening in Academic institutions ranging from primary schools to tertiary institutions all over the African Continent. 


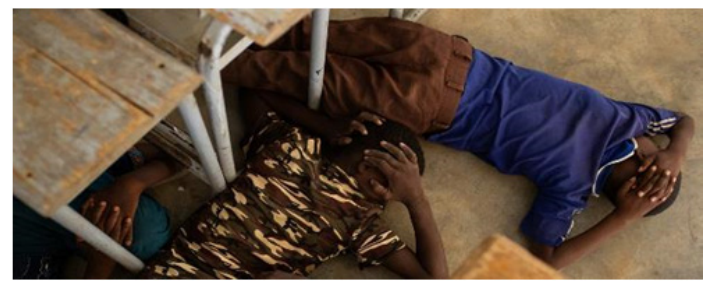

Figure 1: Children take part in an emergency attack simulation, at a primary school in Dori, Burkina Faso in 26 June 2019.

Source: UNICEF, 2019

For instance, according to BBC News (2015), on the 2nd of April 2015, gunmen invaded the Garissa University College in Garissa, Kenya, killing 148 people, and leaving 79 or more injured of which most of the victims were students. The gunmen claimed to be from the militant group and Al-Qaeda offshoot, Al-Shabaab, which admitted to be responsible for the attack. The gunmen took over 700 students' hostage. Also, Fox News (2014) reported the kidnapping of 276 female students from the Government Secondary School in the town of Chibok in Borno State, Nigeria on the night of 14 -15 April 2014. Boko Haram, an extremist terrorist organization based in northeastern region of Nigeria claimed responsibility for the kidnappings (Akali, 2017). Data gathered by United Nations International Children's Emergency Fund on June, 2019 revealed that as a result of insecurity, over 9,ooo schools were closed down in Burkina Faso, Cameroon, Chad, Central African Republic, the Democratic Republic of the Congo, Mali, Niger and Nigeria. This is triple the number of schools shutdown at the end of 2017 (UN, 2019). During these attacks, science infrastructures pivotal to the education of students are destroyed resulting in a major setback in the learning process. Some parents' lives are lost leaving the children uncared for, roaming the streets and unable to complete their education.

\section{Unavailability of Laboratory Equipment and Instructional materials}

Instructional materials are facilities and equipment used by teachers to illustrate and explain lessons for better comprehension of students. These materials are important in the actualization of the science curriculum and enhances better understanding of difficult concepts in science to students (Okoli et al., 2013). The adequacy of laboratory facilities in schools and the teacher's effectiveness in the use of laboratory facilities to facilitate and provide meaningful learning experiences in the learners are what determines the quality of teaching and learning experience (Pareek, 2019).

Several schools in African countries either lack sufficient laboratories, or laboratories are poorly/inadequately equipped, or lack the infrastructure necessary to provide learners with the quality education they are legally entitled to receive (Dike \& Salisu, 2015). Many laboratories take about an hour to setup, science teachers are therefore sometimes faced with the challenge of splitting labs up over the course of a couple of days. Since the teachers spend a lot of time in preparation and set up, they have less time to grade during the normal school hours and often work late or come in early to keep up.

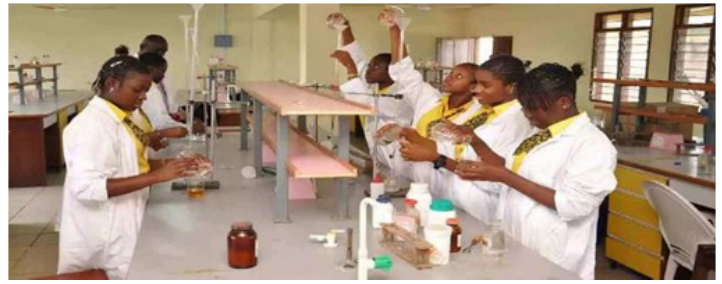

Figure 2: Science Education in Nigeria

Source: https://leadership.ng, 2018 
There is a clear difference between traditional classroom learning and laboratory learning. In the laboratory, students' activities are detailed and they are actively involved in hands-on /interactive engagements using laboratory techniques. These practical activities propel and inspire students to learn more about science with apprehension and at the same time engages them in a process of constructing knowledge where they work individually or in small groups on a question, hypothesis, or question. This hands-on process utilizes science materials that enable students develop their own explanation of the scientific phenomena (Pareek, 2019).

A report investigating the relationship between adequacy and academic performance in chemistry revealed that the adequacy of laboratory facilities has a notable effect on the students' academic performance. This deficiency in science laboratories in Africa has caused a remarkable setback in research which is essential for advancements in different fields including Medicine, Biochemistry, Engineering, and Microbiology among others (Akpan, 2006).

\section{Inadequate Funds}

Quality Science Education demands funding. Poorly equipped workshops, laboratories and libraries in some African Countries' schools exist due to shortfalls and inadequacies in education funding (Nwangwu, 2014). Inadequate funding affects the provision of facilities, infrastructure, and needed number of science teachers (Sani \& Ikpe, 2019). Lack of funding in Science education causes inconducive teaching and learning condition for teachers and students which directly contributes to the poor quality of Science education in Africa (Okoli et al., 2013).

Focusing on quality learning, it is affected by the environmental and school infrastructure through flexibility of the learning space that is able to meet educational needs effectively which will inspire all kind of people, especially those that require special educational needs and flexibility in the use of new technologies. There is a wide gap to fill considering the percentage of the Gross Domestic Product (GDP) of African countries dedicated to education. According to the United Nations News Centre, unless the international community provides an additional $\$ 820$ million, approximately 9.2 million children in conflict and disaster zones will miss out on getting an education (Filippone, 2017).
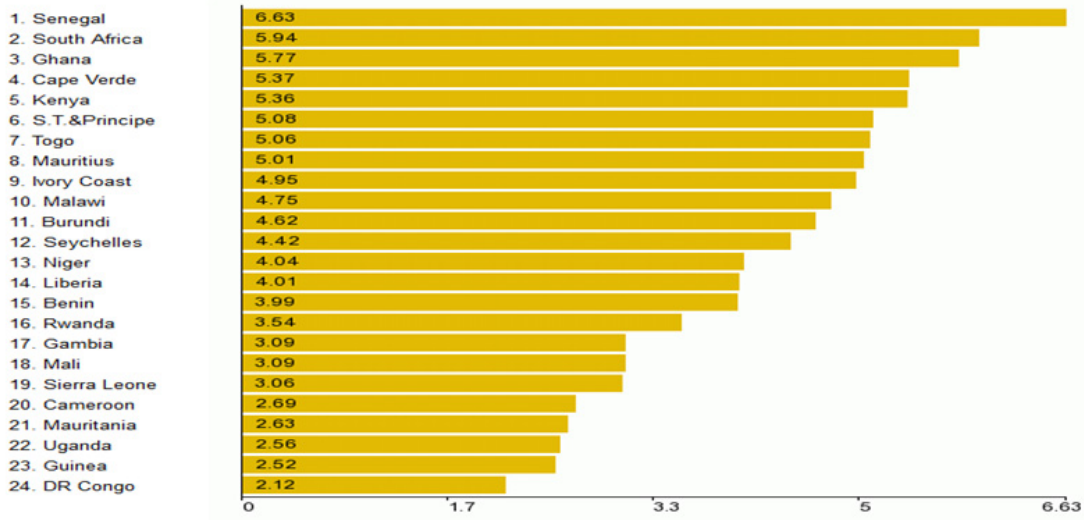

Figure 3: Public spending on education, in percent of GDP, 2016

Source: UNESCO, TheGlobalEconomy.com

In sub-Saharan Africa, only $64 \%$ of primary and $50 \%$ of secondary school teachers possess the minimum required training. However, as a result of schools hiring contract teachers without qualifications to cover gaps at a lower cost; this percentage has been declining since 200o. (Halligan, 2019). 


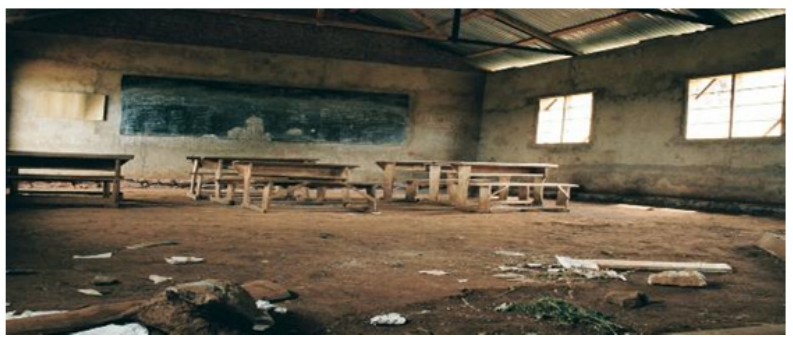

Figure 4: A classroom for Karimu kids

Source: huffpost.com

Fig. 4 above, is a typical example of what inadequate funds to provide the necessary infrastructures required for quality education look like. Due to this pressing issue, infrastructures are not up to the standard required for education to be impacting and productive. Therefore, students do not have access to the quality education they are legally entitled to (Dike \& Salisu, 2015).

\section{Corruption}

According to Nwakamma (2003) corruption covers the whole gamut of bribery, fraud, nepotism, stealing, embezzlement and other corrupt practices. Corruption in education takes various forms and is a viral infection diminishing the quality and socio-economic value of science education in Africa. In countries like Nigeria, Cameroon, Ghana and other West African countries, corruption is manifesting in every sector including education. Admissions of students and appointments of staff are often not based on merit but on who you know or what you can offer. Unfortunately, individuals can purchase slots in the admission list and staff list of universities. Corruption also results in deficiency in the provision of science equipment as there'll be opacity and lack of accountability in the supply process due to the embezzlement by senior officials of institutions. There are various forms of professional misconduct that counts as corruption in education. These conducts include but are not limited to

- Accepting gifts in exchange for positive grades, assessments

- Biased grading based on nepotism or ethnicity

- $\quad$ Sex for grades

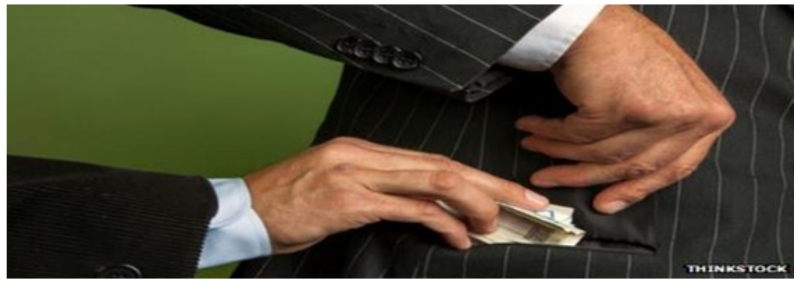

Figure 5: Corruption in Education

Source: Thinkstock

Instances of these occurrences include:

- The arrest of the vice chancellor of the federal University of Agriculture, Abeokuta, Nigeria over alleged financial fraud (The Guardian, 2016).

- The arraignment of the Vice chancellor and Bursar of the Federal University of Technology, Akure, Nigeria over alleged fraud, obtaining money under false pretense, abuse of office and felony (Peter, 2017). 
- The Sex for grades exposé by Kiki Mordi exposing the illicit tradition of lecturers engaging students in sex in exchange for high grades. This was carried out at University of Lagos and University of Ghana exposing lecturers that engage in sex for grades (BBC News, 2019). These corrupt vices are crippling science education advancement in Africa.

\section{Inadequate Teacher Quality and Teaching Method}

Teachers are very critical to the development of science education in all nations across the world. Methods are ways or means by which teachers deliver their lesson presentation thereby making learning experiences tangible to learners. Well-trained teachers are crucial for quality education and what makes a teacher a professional is the teaching methodology he/she uses (Okoli et al., 2013). However, teachers who have not acquired the appropriate pedagogical training to render quality services are teaching students today. The teacher's professional/academic qualifications, knowledge of subject matter, skills and competencies, as well as commitment, have a great impact on the teaching learning process and influence students' performance (Onyeukwu \& Enyaosah, 2016).

Effective teaching is said to occur when students learn and achieve scientific goals and not just limited to being able to repeat scientific knowledge. This depends on the teacher's ability to transform written knowledge into forms that are adaptive to the student abilities and backgrounds and yet pedagogically powerful (Abdulalu, 2007). In science education, inappropriate or non-effective teaching methodology is a vital factor obstructing students' apprehension and achievement. A lot of inexperienced teachers use the abstract approach to teach, thereby making it difficult for students to grasp some scientific concepts, skills and principles as well as making science lessons boring (Onose, 2009). The obsolete method only engages students as mere spectators listening to all that comes from the teachers discouraging creativity and originality (Okoli et al., 2013).

To achieve the objectives of science education, teachers should employ teaching strategies that will enable learners to develop adequate learning strategies which will eventually assist them to acquire basic knowledge, values and skills with the degree of freedom that allows practicality and creativity in their approach to problem solving. The basic skills and abilities of the teaching learning process are developed in a teacher through professional qualification (pre-service and in-service) (Omayuli \& Omayuli, 2009).

\section{Difficult Concepts in Science}

Some Concepts have been identified as difficult in the science curriculum. For example, concepts such as genetics, evolution, perspiration etc. in Biology; electromagnetic field, quantum reality and thermodynamics in Physics; electrochemistry and hydrocarbon in Chemistry are often considered tough by some students. The resources required to simulate these concepts for better comprehension are not available and this has posed a serious issue in the development of science education in Africa. This often results in lack of interest in science subjects by students and they prefer art or social science subjects (Ekanem \& Obodom 2014).

\section{Prospects of Science Education Development in Africa}

The prospect of Science education development in African countries is very unlikely; due to poor Administration, Corruption and deteriorating environmental condition diminish the quality of science education services. Regardless of the challenges drowning the development of science education in Africa, some expectations are discussed below.

\section{Information and Communication Technology}

Considering the level of innovation and invention emerging in form of products and techniques in 
the information sciences, communications, space science/aeronautics, biotechnology, medicine etc. in developed countries; Africa is way behind in regard to its Information and Communication Technology (ICT) sector. It is therefore important for schools and research institutes to take up the challenge. South Korea, USA, and China for example have been producing Smartphone's for over a decade while Africa just opened its first entirely homemade Smartphone in Rwanda (Monks 2019).

Since technology has been integrated into various sectors such as agriculture, education, industry, transportation, health etc. to enhance development, Science Education should be more supple by shedding off the excess weight carried over from the colonial era and re-equip schools with updated, relevant and more efficient resources (Otara, 2012). Also, it has many applications in a technological environment and it will contribute greatly to different sectors and stimulate advancements that ought to already be in use.

\section{Health care}

There are several issues tormenting the Health sector in Africa. According to the World Health Organization (WHO, 2019), more than $90 \%$ of the estimated 300-500 million malaria cases that occur globally every year are in Africans, affecting mainly children under five years of age. Also, the World Africa Region continues to get plagued by Human Immunodeficiency Virus/Acquire Immune Deficiency Syndrome (HIV/AIDS). The region consisting $11 \%$ of world's population has about $60 \%$ of the people living with HIV/AIDS. Proper dissemination of Science Education would not only play a critical role in producing competent scientist that will be responsible for manufacturing homemade vaccines and pills but also enlighten the general public that are not necessarily literate on how to avoid or tackle diseases when they encounter them.

\section{Food Production}

More than 820 million people in the world are undernourished. Sadly, Africa is the continent with the highest prevalence of undernourished people in the world at almost 20\% (FAO, 2019). There are several catastrophic events retarding food production in Africa. For instance, poor harvests and successive crop in some countries like Angola, Mozambique and Zambia and Zimbabwe are taking a toll on agriculture production, resulting in high increase in food prices. In South Africa, dire events resulted in about 41 million people to be food insecure with about 9 million people in the region needing immediate food assistance (World Vison, 2019).

Science education can inform on how to prepare for the hazardous climate occurrences and also how to use mechanized equipment for cultivation, planting and harvesting of crops through the knowledge of Agricultural science. This will not only counteract the hand of fate dealt to Africa by climate change but also improve the production rate of food. Although advancement has been made in crop management technology, they are often under-reported and therefore less visible. This however, does not change the fact that these have made remarkable contributions to increased agricultural productivity (FAO 2003).

\section{Employment}

The advancement of Science Education in Africa will prepare the citizens of the continent for available positions in various industries where they will be directly involved in the research and development of biotechnology, food related items and drugs. According to Samans and Zahidi (2017), employers across Africa identify inadequately skilled workforces as a major limitation to their businesses. This includes $41 \%$ of all firms in Tanzania, 30\% in Kenya, 9\% in South Africa and 6\% in Nigeria. In this modern age, a high percentage of core skills required across occupations will be wholly different by 2020 . Most times, these skills instability springs from the fact that many jobs in the continent are becoming more reliant on the use of digital technologies. Currently, almost all 
professions in African countries including the creative industries, designers, food technologists, data analysts, education and health workers etc. have gone digital. This implies that the Knowledge required to be employable in the nearest future in Africa depends majorly on science education.

\section{Conclusion}

From this submission, we can conclude that there are numerous prospects of science education development in Africa but these prospects are crippled by lots of challenges including the ones stated above like insecurity, corruption, Unavailability of Laboratory Equipment and Instructional materials, Inadequate Funds, Inadequate Teacher Quality and Teaching Method among others. To tackle these problems, the recommendations made below should be considered.

\section{Recommendations}

After the assessment of challenges and prospects of science education development in Africa, the writer would recommend that the following steps should be considered for implementation in order to resolve the problems.

- The Government of African Countries should increase the funds allocated for the development of Education. Also, non-governmental organizations should donate laboratory equipments to both secondary and tertiary institutions.

- Science Education teachers and lecturers should be sponsored for seminars, conferences and training sessions to ensure they are up to date on the latest development in science education.

- There should be seminars and conferences organized to enlighten and refresh the minds of science education students. Creating awareness of challenges they might face and how they can work on themselves to advance the development of science education.

- Science Students should be trained to work and adapt to new environments. They should also be trained to work in teams as this will foster a creative and innovative environment.

- Science Education curriculum and methodology should be reviewed in Africa. This involves revision from old and outdated pedagogies and curricular structures to new methodologies in line with recent employment needs and entrepreneurship.

- Strict judgment and regulations should be in place to curb the pestilence of corruption in the education system in Africa. Especially cases of bribery, nepotism, sex for grades among others should be shunned and condemned at every opportunity.

\section{Acknowledgement}

I will like to thank God who in his infinite mercy and grace has made this write up possible. Also, I want to appreciate the authors of the publications that were pivotal to the success of this report. Finally, I want to thank my family for their moral support

\section{References}

Aina, J. (2012). Challenges and Prospects of Primary Science Teaching in Nigeria. Continental J. Education Research, 5 (2): 32-37.

https://doi:10.5707/cjeducres.2012.5.2.32.37

Akali, O. (2017). The Chibok Kidnappings in North-East Nigeria: A Military Analysis of Before and After. Small Wars Journal, 13(4). http://smallwarsjournal.com/jrnl/art/the-chibok-kidnappings-in-north-east-nigeria-amilitary-analysis-of-before-and-after

Akintunde, O. \& Selzing-Musa, G. (2016). Environmental Insecurity and the Nigerian Child's Learning: Coping Strategies. Asia Pacific Journal of Multidisciplinary Research, 4(1),13-17. 
Akpan, O. (2006). “Laboratory Facilities for Chemistry Teaching”. Unpublished Seminar Paper. Nigeria: University of Calabar.

Badmus, O. T. \& Omosewo, E. O. (2018). Improving Science Education in Nigeria: The Role of Key Stakeholders. European Journal of Health and Biology Education, 7(1), 1-5. https://doi.org/10.29333/ejhbe/87086

BBC News. (2015, April 4). Kenya al-Shabab attack: Security questions as Garissa dead mourned. Retrieved October 30, 2019, from https://www.bbc.com/news/world-africa-32177123/

BBC News. (2019, October 7). Sex for grades: Undercover in West African universities. Retrieved October 30, 2019, from https://www.bbc.com/news/av/world-africa-49907376/sex-for-grades-undercover-in-west-africanuniversities

Bhoje, G. (2014). Application of Motivational Theory in Classroom Situation (2nd ed.). Laxmi Book Publication, Solapur, India.

Dike, N. \& Salisu, H. (2015). Inadequate Laboratory Facilities and Utilization: Pedagogical Hindrance to Students' Academic Performance in Biology in Senior Secondary Certificate Examination in Zaria Metropolis, Kaduna State, Nigeria. International Business Research, 8(9), 124-134.

Duncan, A. (2013, April 23). Education: The Most Powerful Weapon for Changing the World. USAID. http://blog.usaid.gov/wpcontent/uploads/2013/o4/7783405658_7e214411de_o.jpg

Ekanem, M. U. \& Obodom, M. I. (2014). Education for All: Problems and Prospects of Science Education in Nigerian School. Journal of Resourcefulness and Distinction, 8 (1), 1-4.

FAO (2003). World Agriculture towards 2015/2030: An FAO Perspective, London: earthscan

FAO, IFAD, UNICEF, WFP and WHO. (2019). The State of Food Security and Nutrition in the World 2019. Safeguarding against economic slowdowns and downturns. Rome, FAO. http://www.fao.org/3/ca5162en/ca5162en.pdf

Filippone, J. (2017, July 19). Lack of Funding Prevents Education for Children in Conflict and Disaster Zones. Edtechtimes. Retrieved October 31, 2019, from https://edtechtimes.com/2017/o7/19/funding-educationchildren-in-conflict-disaster-zones/

Fox News. (2014, June 23). Nigeria says 219 girls in Boko Haram kidnapping still missing. Retrieved October 30, 2019, from https://www.foxnews.com/world/nigeria-says-219-girls-in-boko-haram-kidnapping-still-missing

Halligan, A. (2019, July 9). Funding gaps derailing universal education in Africa. CGTN Africa. Retreived October 31, 2019, from https://africa.cgtn.com/2019/o7/o9/funding-gaps-derailing-universal-education-in-africa/

Igbaji, C., Bello, M. \& Sanus, S. (2017). Science Education and Nigeria National Development Effort: The Missing Link. International Institute of Academic Research and Development, 3(5), 46-56.

Monks, K. (2019, October 8). Rwanda opens 'first entirely homemade' Smartphone factory in Africa. CNN. Retrieved November 1, 2019, from https://edition.cnn.com/2019/10/o8/africa/rwanda-smartphonefactory/index.html

Nnaboua, P. O. \&Asodike, J. D. (2014). Exploring Education as a Tool for Sustainable Development in Nigeria. European Scientific Journal 8(10) 1-11

Nwakamma, P. C. (2003). The influence of Corruption on the Value of the Manufacturing Concern. The Enterprise (International Research Journal for Development, 5(1), 20-31.

Nwangwu, R. (2014). Teachers for Technology: Basic Principles of School Technology Report. PATT 3 Conference, 2, $487-493$.

Ohunene, O. C. \& Ebele, O. B. (2014). Science Education and Sustainable Development in Nigeria. American Journal of Educational Research, 2(8), 595-599. DOI:10.12691/education-2-8-6

Okafor, N. (2004). Science Education for National Development and Self-reliance in a Deregulated Economy. Journal of the Nigerian academy of education, 1(2), 76- 87 .

Okafor, P. N. (200o). Difficult Concepts in physics as experienced by senior secondary students in Akwa Ibom State. Journal of Research Information in Education, 1(1), 114-121.

Okoli, S., Obiajulu, A. \& Ella, F. (2013). Science Education for Sustainable Development in Nigeria: Challenges and Prospects. Academic Journal of Interdisciplinary Studies, 2(6), 159-165. https://doi:10.5901/ajis.2013.v2n6p159

Omayuli, M. O. \& Omayuli, V. O. (2009). Reforms and Innovation in Science Education; The Way Forward. Journal of Teacher Perspective. 3(2)181-185.

Onah, A.O. (2003). Science Education and Poverty Eradication in Nigeria" Eha -Amufu School of Education Journal 3(1) 181 .

Onose, G. M. Okogun E. A \& Richard J. (2009) Reforms and Innovation in Training and Retraining of Science and Mathematics Teachers to meet with the Challenges of Global Development. Journal to Teacher Perspective, 3(2), 181-184. 
Onyeukwu, I. \& Enyaosah, U. (2016). Ways of Bridging the Gap Between Teaching and Research in Science Education in a Reflective Society in Nigeria. Multidisciplinary Journal of Research Development, 25(1), 1-8.

Otara, A. (2012). The Future of Education and Its Challenges in Africa. International Journal of Humanities and Social Science, 2(9), 151-156.

Pareek, R. B. (2019). An Assessment of Availability and Utilization of Laboratory Facilities for Teaching Science at Secondary Level. Science Education International, 30(1), 75-81.

Pember, S. T. \& Humbe, T. T. (2009, October 6-9). Science Education and National Development [Paper Presentation]. ASSUTIBS Maiden National Conference, CEO Katsina- Ala, Nigeria.

Peter, D. (2017, February 14). EFCC arraigns FUTA VC, bursar in Ondo. Punch NG. Retrieved November 1,2019 from https://punchng.com/efcc-arraigns-futa-vc-bursar-in-\%E2\%8o\%8Eondo/

Robinson, N. (2019, January 23). Poor-quality teachers are holding back South Africa's education system. News24. Retrieved November 1, 2019, from https://www.news24.com/SouthAfrica/Local/Maritzburg-Fever/poorquality-teachers-are-holding-back-south-africas-education-system-20190116-2

Samans, R. \& Zahidi, S. (2017). The Future of Jobs and Skills in Africa: Preparing the Region for the Fourth Industrial Revolution. World Economic Forum Submit, pg iii

Sani, D. \& Ikpe, A. (2019). Science Education and Sustainable Development in Nigeria: An Analytic Approach. Journal of Humanities and Social Science, 24(6), 29-34. https://doi:10.979o/o837-2406032934

Taber, K. (2017). Science Education as a field of Scholarship. K. S. Taber \& B. Akpan (Eds.), Science Education: An International Course Companion (pp. 3-19). Sense.

The Guardian EFCC arrests vice chancellor of FUNAAB [Editorial]. (2016, November 23). The Guardian Retrieved November 1, 2019 from https:/guardian.ng/news/efcc-arrests-vice-chancellor-of-funaab/

UN News School closures triple in Central and Western Africa as education comes under fire. (2019, August 23). UN News. Retrieved October 30, 2019, from https://news.un.org/en/story/2019/o8/1044821

World Health Organization, The African Regional Health Report: The Health of the People. WHO Bulletin Volume 97. November 2019. Retrieved November 1, 2019 from https:/www.who.int/bulletin/africanhealth/en/

World Vision Africa hunger, famine: Facts, FAQs, and how to help. (2019, October 24) World Vision. Retrieved November 2, 2019, from https://www.worldvision.org/hunger-news-stories/africa-hunger-famine-facts

Yoldere, H. M. \& Adamu, M. (2014). The Challenges Facing Science Education in Developing Countries and the Way Forward. International Journal of Scientific Engineering and Research, 3(11), 84-89. 